\title{
Perancangan Website Profil Sekolah Madrasah Tsanawiyah Negeri 2 Medan
}

Zulfikri Siregar ${ }^{1}$, Ramli², Ika Sari ${ }^{3}$.

1,2,3, Universitas Harapan Medan

Corresponding Author : Zulfikrisiregar26@gmail.com

ABSTRACT
In Madrasah Tsanawiyah Negeri 2 Medan, the process of school profile
information still uses brochures, pamphlets, banners and delivery through the
students themselves so that the scope of promotion does not extend to other
areas. To make it easy for the community to see the profile of the Mtsn 2 School
and to make it easy for employees to input school profile information data, the
authors designed a Web-based system. In the process of collecting data with the
aim of solving problems, the authors used descriptive data collection methods,
namely observation and interviews. Here the author uses a Web-based system.
This website was developed using PHP and MYSQL software. This website
contains the vision and mission, organizational structure, teacher data, employee
data, academic, non-academic activity data and facility data. Which aims to
introduce the Mtsn 2 Medan school to the general public. Based on the results of
the tests that have been carried out, this Web-based school profile system can help
Mtsn 2 Medan School in promoting the school to the wider community and is
able to facilitate employee work.

\section{PENDAHULUAN}

Sistem Informasi adalah kombinasi dari teknologi informasi dan aktivitas orang yang menggunakan teknologi itu untuk mendukung operasi dan manajemen sistem informasi yang sering digunakan merujuk kepada interaksi antara orang, proses algoritmik,datadanteknologi. Dengan adanya teknologi informasi dapat mempermudah kinerja pegawai dan meningkatkan mutu perusahaan maupun instansi pemerintah dalam pengelolaan data. Sistem adalah suatu jaringan kerja dari prosedur-prosedur yang saling berhubungan, terkumpul bersama-sama untuk melakukan suatu kegiatan atau untuk tujuan tertentu. (Yakub, 2012:1).

Informasi adalah data yang telah di proses sedemikian rupa sehingga meningkatkan pengetahuan seseorang yang menggunakan. Para pembuat keputusan memahami bahwa informasi menjadi factor kritis dalam menentukan kesuksesan atau kegagalan dalam suatu bidang usaha. Informasi data berupa dapat berupa data mentah, data tersusun, kapasitas sebuah saluran informasi dan sebagainya. (Yakub,2012:8)

Sistem informasi juga merupakan suatu kumpulan dari komponenkomponen dalam organisasi yang berhubungan berhubungan dengan proses 
penciptaan dan aliran informasi. Pada lingkungan berbasis komputer, sistem informasi menggunakan perangkat keras dan lunak komputer, jaringan telekomunikasi, manajemen bisnis basis data, dan berbagai bentuk teknologi informasi yang lain dengan tujuan untuk mengubah sumber data berbagai macam informasi yang di butuhkan oleh pemakai. (Yakub,2012:17).

Website adalah sebuah kumpulan halaman pada suatu domain di internet yang dibuat dengan tujuan tertentu dan saling berhubungan serta dapat diakses secara luas melalui halaman depan (home page) menggunakan sebuah browser dan terdiri dari URL. Website berfungsi untuk suatu wadah perusahaan untuk menyampaikan suatu informasi pesan kepada masyarakat yang bertujuan menguntungkan suatu perusahaan atau instansi.

Sekolah Madrasah Tsanawiyah Negeri 2 Medan merupakan tempat belajar siswa dengan guru sebagai pengajar yang berlandaskan ajaran agama islam.. Keberadaan sekolah Madrasah Tsanawiyah Negeri 2 Medan berlokasi di Jl. Peraturan, Kenangan Baru, Kec. Percut Sei Tuan, Kabupaten Deli Serdang, Sumatera Utara 20371, berdiri pada tahun 1995 dengan jumlah siswa lebih dari 500 orang dan memiliki pengajar 85 orang. Adapun kegiatan-kegiatan akademik seperti proses pembelajaran, mengadakan ujian try out sebelum UN, mengadakan seleksi cerdas cermat untuk mewakili sekolah dalam Olimpiade IPTEK, mengadakan Les atau pelajaran tambahan. Sedangkan kegiatan-kegiatan non akademik seperti keterampilan pidato Bahasa Arab, keterampilan pidato Bahasa Inggris, keterampilan melukis, Kaligrafi, Seni Tari, Nasyid, Paskibra, PMR, Futsal, Basket, Hoki, Pencak Silat, Volly dan Drum Band. Sarana dan Prasarana meliputi Lapangan Olahraga Serbaguna, Masjid, Miniatur Ka'bah, Sanggar Pramuka dan lain-lain. Untuk mengsosialisasikan kondisi-kondisi diatas kepada masyarakat adalah dilakukan dengan penyampaian melalui siswa-siswi masing-masing, spanduk, membagikan brosur dan lain-lain.Dari permasalahan di atas dapat dibuat suatu sistem yang mampu membantu untuk mengatasi permasalahan yang dapat diimplementasikan dalam bentuk perangkat lunak yang terkomputerisasi, dalam sistem berbasi Web dengan menggunakan bahasa pemograman PHP. Maka dalam hal ini memilih judul penelitian ini "Perancangan Website Profil Sekolah Madrasah Tsanawiyah Negeri 2 Medan". 
Cybernetics: Journal of Research and Educational Studies

Volume 2 Nomor 4, Oktober 2021

Halaman 81-95

\section{METODE PENELITIAN}

Metode penelitian ini menggunakan pendekatan penelitian kualitatif dengan teknik pengumpulan data melaluai observasi, wawancara dan studi pustaka. Observasi merupakan teknik mengumpulkan data dengan melakukan tinjauan langsung ke tempat dimana dilakukan penelitian. Dalam hal ini peneliti melakukan observasi ke sekolah Madrasah Tsanawiyah Negeri 2 Medan. Teknik mengumpulkan data dengan wawancara ini dilakukan untuk mengumpulkan data dan mendapatkan informasi tambahan dengan cara mewawancarai pihakpihak terkait, dalam hal ini saya melakukan wawancara langsung kepada kepela sekolah salman munthe maupun kepala sekolah selaku orang penting di sekolah Madrasah Tsanawiyah Negeri 2 Medan. Studi pustaka yaitu membaca dan mempelajari buku-buku dan artikel yang berhubunngan dengan sistem pendukung keputusan khususnya tentang perancangan sistem, serta buku-buku yang mendukung dengan masalah yang dibahas dalam penyusunan Tugas Akhir.

Tahapan proses penelitian seperti :

1. Menganalisis penerapan Perancangan dan Pembuatan Website Pada sekolah Madrasah Tsanawiyah Negeri 2 Medan untuk meningkatkan mutu instasi sekolah.

2. Merancang sistem, dari hasil analisis yang diperoleh maka dilakukan teknik merancang sistem untuk membuat pengembangan dari sistem berbasi Web yang digunakan.

3. Menguji sistem, setelah proses mengimplementasikan selesai maka akan dilakukan proses terhadap program yang telah dibuat untuk mengetahui apakah program sudah selesai dalam menghasilkan laporan Profil Sekolah.

4. Mengimplementasikan sistem, pada tahap ini dilakukan pemanfaatan program dalam melakukan proses perancangan Profil Sekolah.

\section{HASIL PENELITIAN DAN PEMBAHASAN}

\section{Analisa Sistem Yang Sedang Digunakan}

Proses analisa sistem merupakan tahap selanjutnya dalam menganalisa permasalahan dalam sistem dan solusi untuk memecahkan permasalahan suatu sistem. Sekolah Madrasah Tsanawiyah Negri 2 Medan merupakan tempat belajar siswa dengan guru sebaga pengajar yang berlandaskan ajaran agama islam. Keberadaan sekolah Madrasah Tsanawiyah Negri 2 Medan berlokasi di Jl. Peraturan, Berdiri pada tahun 1995 dengan jumlah siswa lebih dari 500 orang dan memiliki pengajar 85 orang. Adapun kegiatan-kegiatan akademik seperti proses pembelajaran, mengadakan ujian try out sebelum UN, mengadakan seleksi cerdas cermat untuk mewakili sekolah dalam Olimpiade IPTEK, 
Cybernetics: Journal of Research and Educational Studies

Volume 2 Nomor 4, Oktober 2021

Halaman 81-95

mengadakan Les atau pelajaran tambahan. Sedangkan kegiatan-kegiatan non akademik seperti keterampilan pidato Bahasa Arab, keterampilan pidato Bahasa Inggris, keterampilan melukis, Kaligrafi, Seni Tari, Nasyd, Paskibra, PMR, Futsal, Basket, Hoki, Pencak Silat, Volly dan Drum Band. Sarana dan Prasarana meliputi Lapangan Olahraga Serbaguna, Masjid, Miniatur Ka'bah, Sanggar Pramuka dan lain-lain.

Profil Website Sekolah Madrasah Tsanawiyah Negri 2 medan merupakan tampilan informasi sekolah tentang keseluruhan yang ada di Sekolah Madrasah Tsanawiyah Negri 2 Medan. Contoh prestasi sekolah, sejarah berdirinya sekolah, Visi Misi sekolah dan informasi guru maupun pegawai, kegiatan akademik, non akademik, dan informasi mengenai sarana dan prasarana.

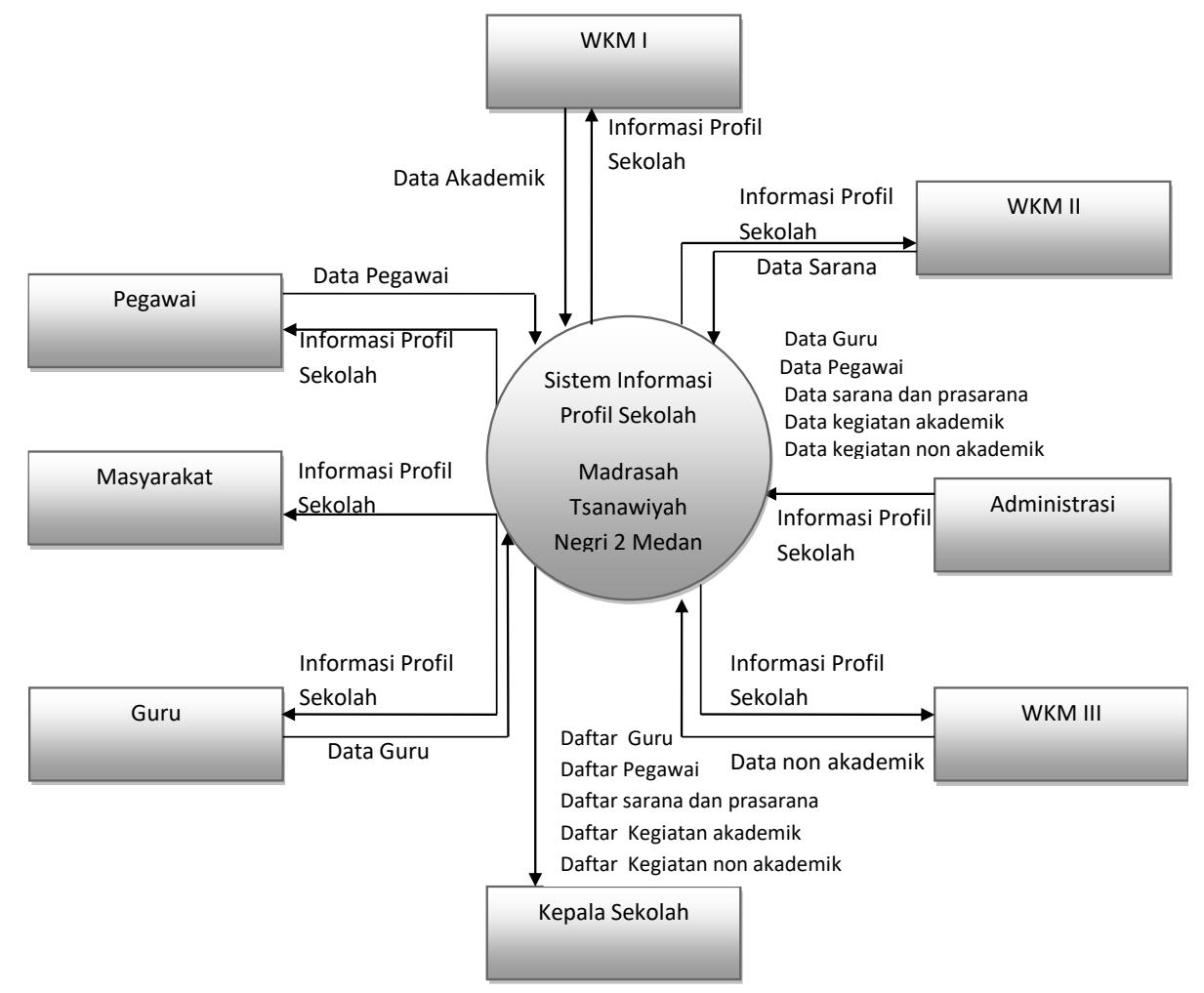

Gambar 1. Diagram Konteks yang sedang berjalan

Adapun kendala yang di hadapi pada sistem yang sedang berjalan di Sekolah Madrasah Tsanawiyah Negri 2 adalah sebagai berikut :

1. Promosi masih menggunakan brosur, pamplet, spanduk dan penyampaian melalui siswa itu sendiri sehingga cakupan promosi kurang meluas kedaerah- daerah lain.

2. Sistem tidak bisa diakses secara umum tentang profil Sekolah Madrasah Tsanawiyah Negri 2 Medan. 
Cybernetics: Journal of Research and Educational Studies

Volume 2 Nomor 4, Oktober 2021

Halaman 81-95

3. Sistem tidak ada penyimpan data tentang sekolah maupun data guru untuk mengantisipasi jika data kehilangan atau rusak.

Dari kendala-kendala diatas dapat diambil kesimpulan bahwa masih banyak kendala terhadap sistem profil Sekolah Madrasah Tsanawiyah Negri 2 Medan. Adapun solusi yang dapat menjawab kendala-kendala diatas antara lain:

1. Membuat sebuah sistem informasi berbasis web yang dapat memproses dan menampilkan informasi sekolah yang dapat di backup dan di simpan dalam memberikan Laporan data profil sekolah.

2. Memperkenalkan kepada masyarakat umum mengenai sekolah MTSN 2 Medan melalui Website.

3. Mempermudah kerja pegawai dalam mendapatkan data tentang profil sekolah di Mtsn 2 Medan.

\section{Perancangan Sistem}

Peracangan sistem dapat membantu dan membangun suatu sistem yang akan dibangun dalam percangan website Profil Sekolah Madrasah Tsanawiyah Negri 2 Medan yang dapat mebantu proses alur kerja sistem yang dihasilkan dalam suatu aplikasi pemograman berbasis web.

Adapun perancangan sistem yang dapat diusulkan untuk mengembangkan sistem informasi Profil Sekolah yang sedang berjalan pada Sekolah Madrasah Tsanawiyah Negeri 2 Medan dengan perancangan sebuah sistem baru berbasis Web, adapun data-data yang ada pada sistem baru antara lain :

1. Data Guru, berisikan kode guru, nama, alamat, jabatan, jenis kelamin, gambar, guru pelajaran.

2. Data Pegawai, berisikan kode pegawai, nama, alamat, jabatan, jenis kelamin, gambar.

3. Data Sarana dan Prasarana, berisikan kode sarana, nama sarana, jumlah.

4. Data Kegiatan Akademik, berisikan kode akademik, nama akademik

5. Data Kegiatan non Akademik, berisikan kode nonakademik, nama nonakademik

Data-data diatas direkam dan disimpan dengan menggunakan computer, dengan program komputer Sistem Informasi Profil Sekolah Madrasah Tsanawiyah Negeri 2 Medan berbasis Web. Dimana program ini menyediakan fasilitas perekaman data, penghapusan data, pencarian dan juga proses percetakan data untuk laporan.

Data yang direkam akan disimpan ke file database dengan ketentuan :

1. Data Guru direkam dan disimpan ke dalam tabel Guru

2. Data Pegawai direkam dan disimpan ke dalam tabel Pegawai 
Cybernetics: Journal of Research and Educational Studies

Volume 2 Nomor 4, Oktober 2021

Halaman 81-95

3. Data Sarana dan Prasarana direkam dan disimpan ke dalam tabel Saranaprasarana

4. Data Kegiatan Akademik direkam dan disimpan ke dalam tabel Akademik

5. Data Kegiatan non Akademik direkam dan disimpan ke dalam tabel nonAkademik

Data yang diproses untuk menghasilkan output, dimana percetakan output atau Daftar tersebut dilakukan oleh komputer yang telah di program pada program Website sekolah Madrasah Tsanawiyah Negeri 2 Medan. Sistem Informasi Website profil Sekolah Madrasah Tsanawiyah Negeri 2 Medan menghasilkan sebuah Output :

1. Daftar Data Guru

2. Daftar Data Pegawai

3. Daftar Data Sarana dan Prasarana

4. Daftar Data Kegiatan Akademik

5. Daftar Data Kegiatan non Akademik

Sehingga Lebih efektif dan efesien dalam proses pendataan dan pembuatan Daftar, Dimana pengerjaanya sangat cepat dan mudah. Selain itu, data yang telah di edit ke sistem maka sangat aman tersimpan di media penyimpanan. Sistem yang diusulkan ini juga dapat menyajikan informasi dengan mudah dan cepat.

\section{Diagram Konteks}

Diagram konteks dapat juga diartikan sebagai pengaplikasian program yang sedang dibuat oleh programmer ke dalam bentuk tulisan atau gambar, tulisan atau gambar inilah nantinya akan mempermudah seseorang untuk membaca bagaimana program yang dibuat tersebut berjalan, tetapi kelemahan dari diagram konteks ini adalah hanya mengartikan program secara garis besar saja.

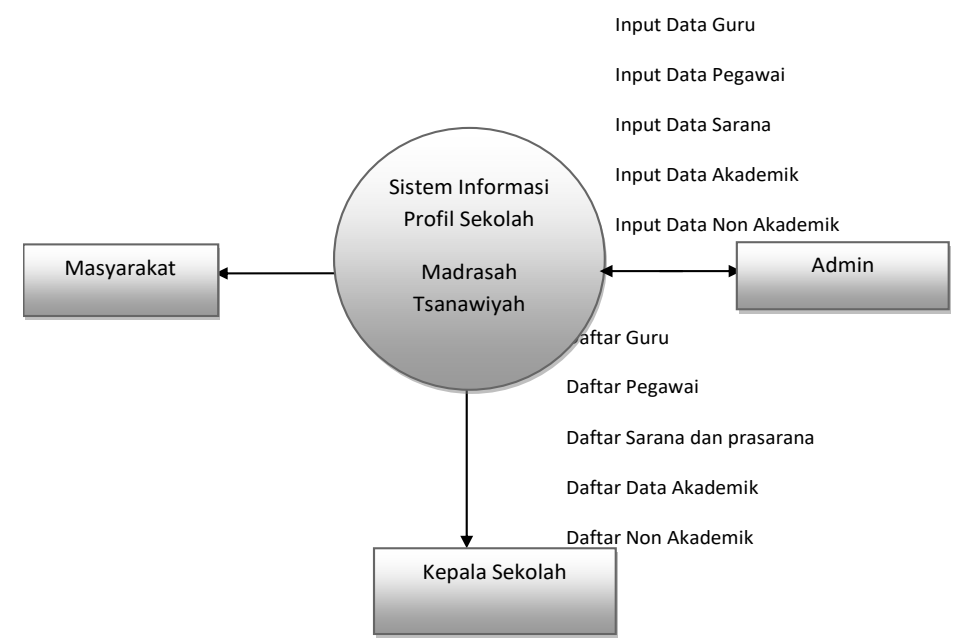

Gambar 2. Diagram Konteks 
Cybernetics: Journal of Research and Educational Studies

Volume 2 Nomor 4, Oktober 2021

Halaman 81-95

Keterangan :

Berdasarkan diagram konteks diatas maka dapat dijelaskan bahwa admin menginput data guru, data pegawai, data sarana dan prasarana, data akademik dan data non akademik kedalam sistem informasi profil sekolah. Kemudian mengontrolnya sehingga masyarakat dapat menerima informasi data tentang profil sekolah dan kepala sekolah dapat melihat informasi profil sekolah dan menerima laporan daftar guru, daftar pegawai, daftar sarana dan prasarana, daftar akademik dan daftar non akademik dari website Profil Sekolah Madrasah Tsanawiyah Negri 2 Medan.

\section{Data Flow Diagram (DFD)}

DFD merupakan detail rancangan dari diagram konteks yang sudah dibuat dan memuat rancangan tabel database yang akan diimplementasikan pada database yang akan dibuat. Adapun rancangan data flow diagram yang diusulkan antara lain :

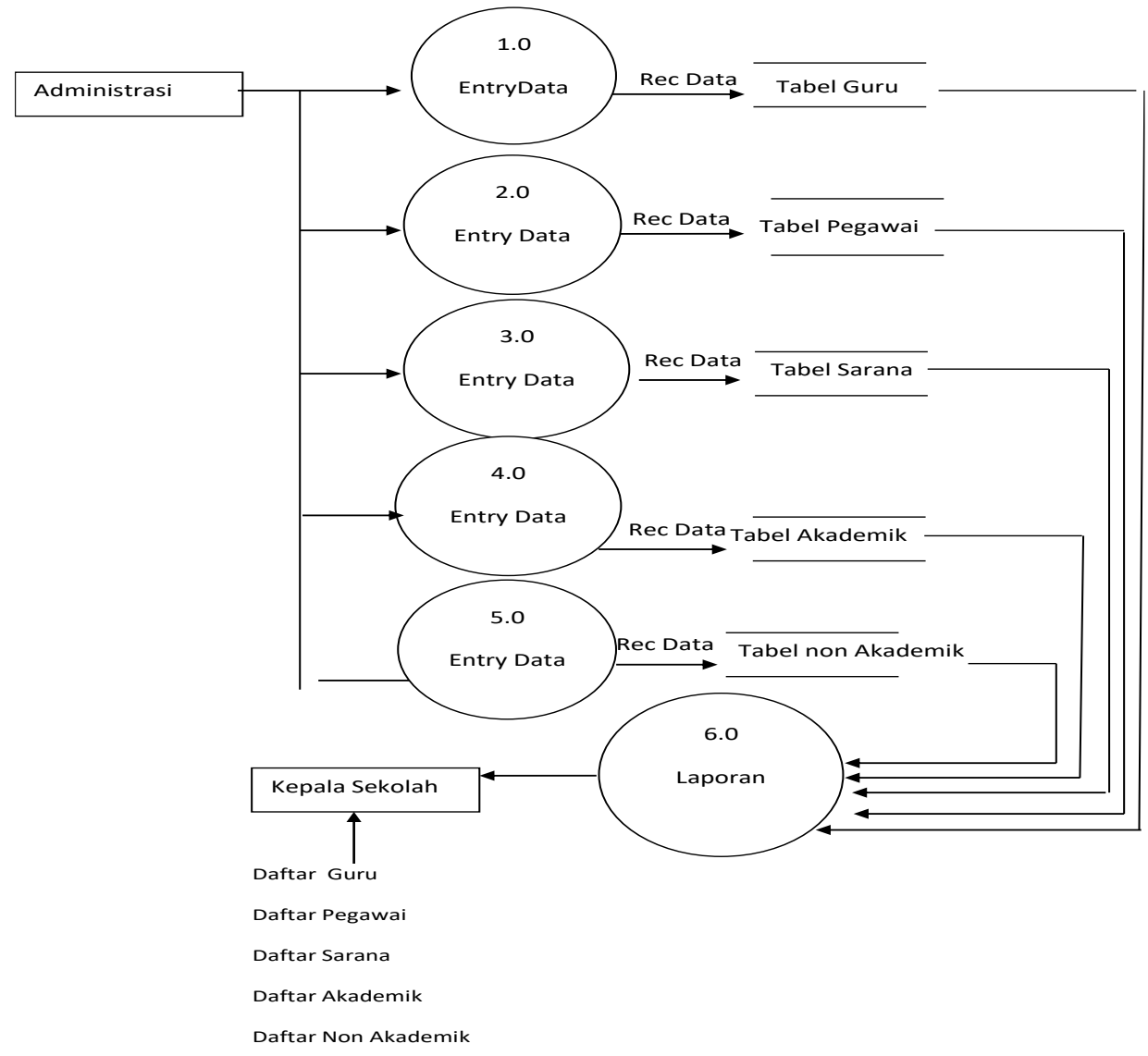

Gambar 3. DFD (Data Flow Diagram) Level 0 
Cybernetics: Journal of Research and Educational Studies

Volume 2 Nomor 4, Oktober 2021

Halaman 81-95

\section{Data Guru}

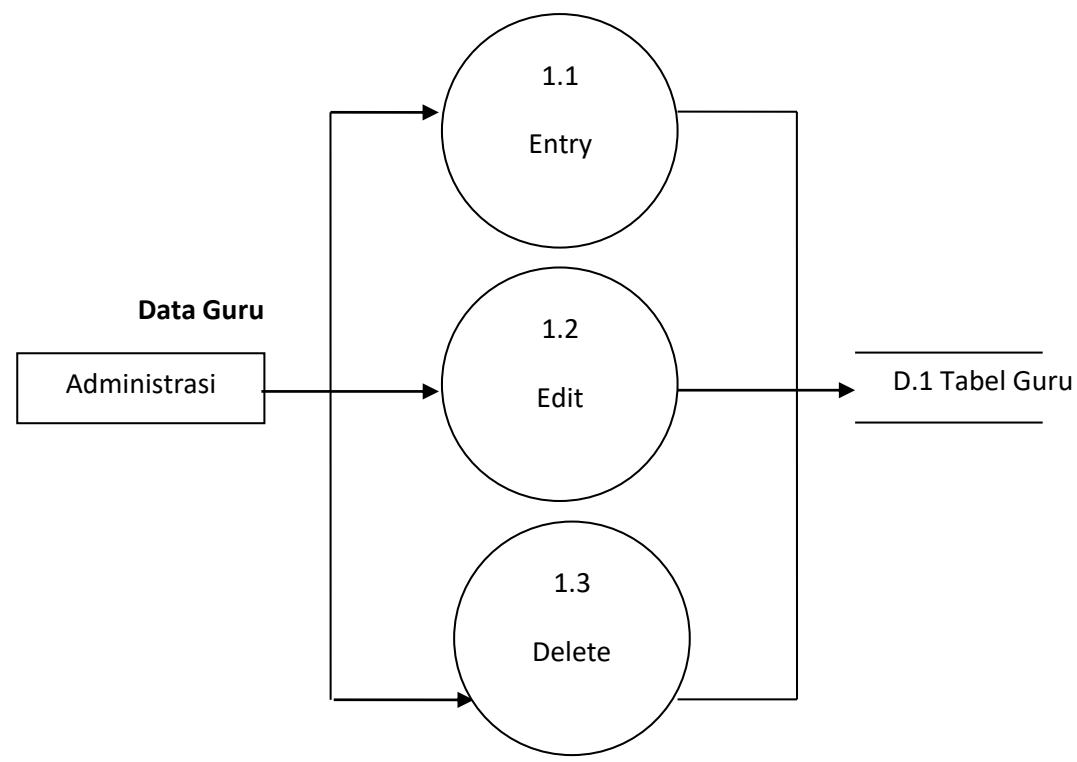

Gambar 4. DFD (Data Flow Diagram) Level 1 Proses 1.0

\section{Data Akademik}

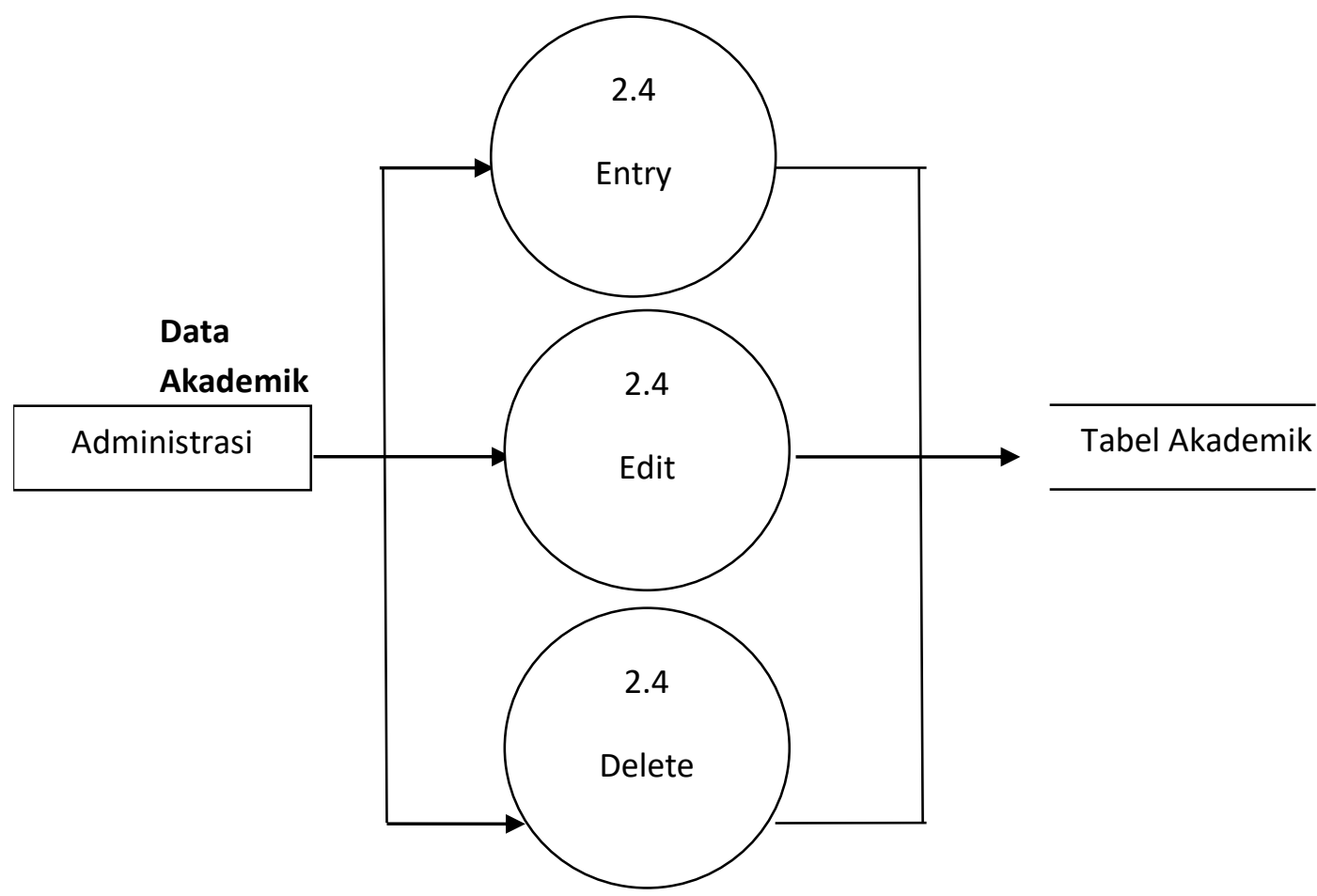

Gambar 5. DFD (Data Flow Diagram) Level 2 Proses 4.0 
Cybernetics: Journal of Research and Educational Studies

Volume 2 Nomor 4, Oktober 2021

Halaman 81-95

\section{Data non Akademik}

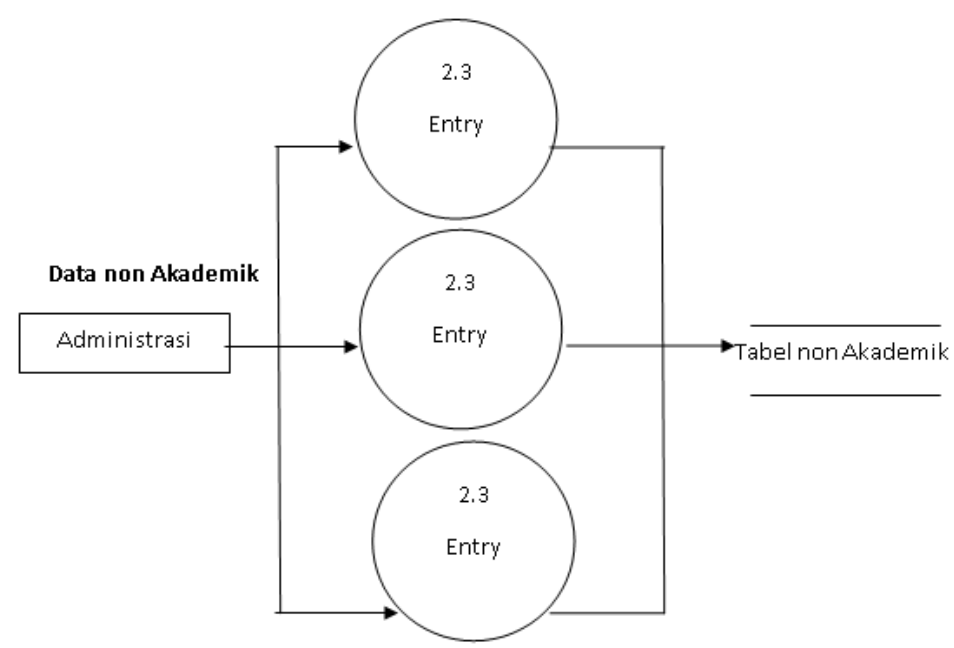

Gambar 6. DFD (Data Flow Diagram) Level 2 Proses 5.0

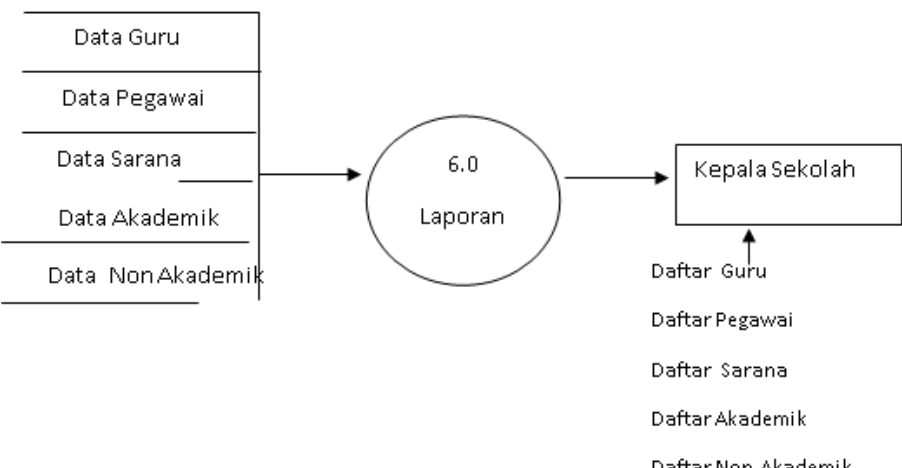

Gambar 7. DFD (Data Flow Diagram) Level 1 Proses .0

\section{Perancangan Database}

Perancangan database adalah tahapan yang dilakukan untuk mendisain atau merancang tabel-tabel data yang berfungsi sebagai tempat penyimpanan data yang saling berhubungan sebagai sebuah basis data atau database. Perancangan database dilakukan berdasarkan data yang diperoleh dari sistem yang sedang digunakan.

Entity Relationship Diagram (ERD)

Diagram Hubungan Entitas atau entity relation diagram merupakan model data berupa notasi grafis dalam pemodelan data konseptual yang menggambarkan hubungan antara penyimpan. 


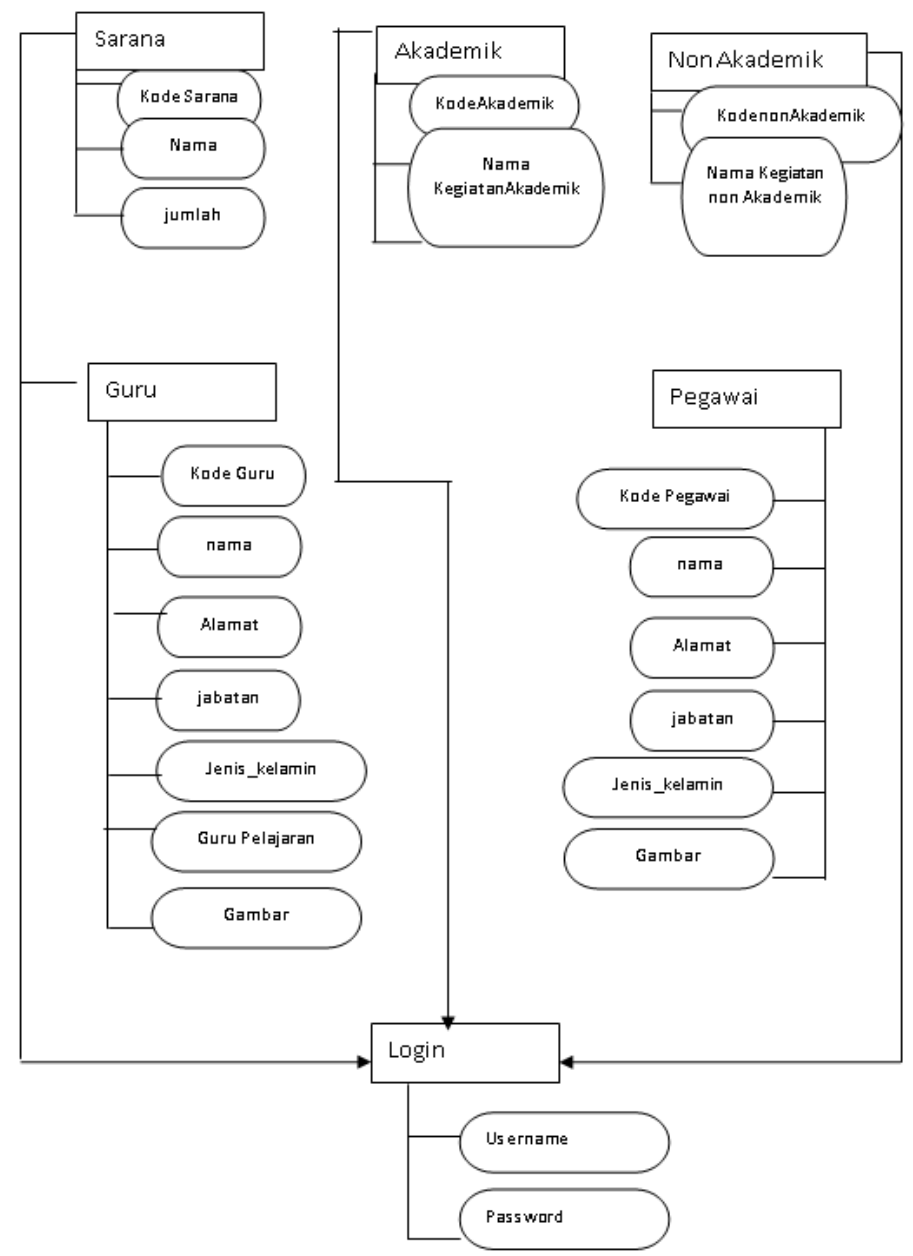

\section{Gambar 8. Entity Relationship Diagram (ERD)}

\section{Perancangan Ouput}

Perancangan Output merupakan perancangan yang berkaitan dengan informasi hasil pengolahan data. Perancangan output bertujuan untuk mengubah data menjadi informasi yang berguna dan dapat digunakan sebagai dasar pengambilan keputusan yang tepat. Rancangan keluaran untuk sistem yang diusulkan terdiri dari racancangan output menghasilkan informasi tentang sekolah. Adpun rancangan

Rancangan Daftar informasi tentanga data sekolah atau kegiatan sekolah percangan website Profil Sekolah Madrasah Tsanawiyah Negri 2 Medan. 
Cybernetics: Journal of Research and Educational Studies

Volume 2 Nomor 4, Oktober 2021

Halaman 81-95

Daftar Guru:

Sekolah Madrasah Tsanawiyah Negri 2 Medan

Logo

\begin{tabular}{|c|c|c|c|c|c|c|}
\hline $\begin{array}{c}\text { Kode } \\
\text { Guru }\end{array}$ & $\begin{array}{c}\text { Nama } \\
\text { Guru }\end{array}$ & Alamat & Jabatan & $\begin{array}{c}\text { Jenis } \\
\text { Kelamin }\end{array}$ & $\begin{array}{c}\text { Mata } \\
\text { Pelajaran }\end{array}$ & Gambar \\
\hline 9999999 & xxxxxxx & xxxxxxx & xxxxxxx & xxxxxxx & xxxxxxx & xxxxxxx \\
\hline & & & & & \\
\hline
\end{tabular}

Gambar 9. Daftar Guru

Medan, 99-99-9999

Ka. Sekolah

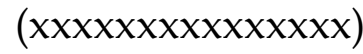

\section{Perancangan Input}

Rancangan input merupakan uraian tentang variable atau field yang terdapat pada tabel-tabel database yang digunakan untuk memasukkan dan menangkap data. Rancangan input sangat memegang peranan penting, karena seluruh data yang disimpan dalam table database terlebih dahulu di entry pada bagian ini.

Pada rancangan input data guru ini, digunakan untuk memasukkan data guru. Form ini dirancang untuk melakukan penginputan record data guru seperti kode guru, nama guru, alamat, jabatan, jenis kelamin, guru pelajaran dan gambar. 
Cybernetics: Journal of Research and Educational Studies

Volume 2 Nomor 4, Oktober 2021

Halaman 81-95

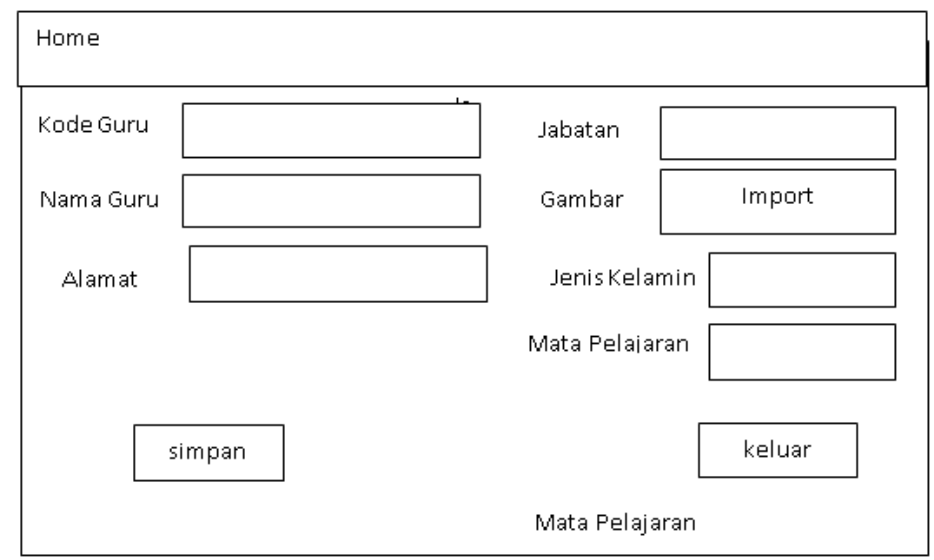

\section{Tampilan Input Data Guru}

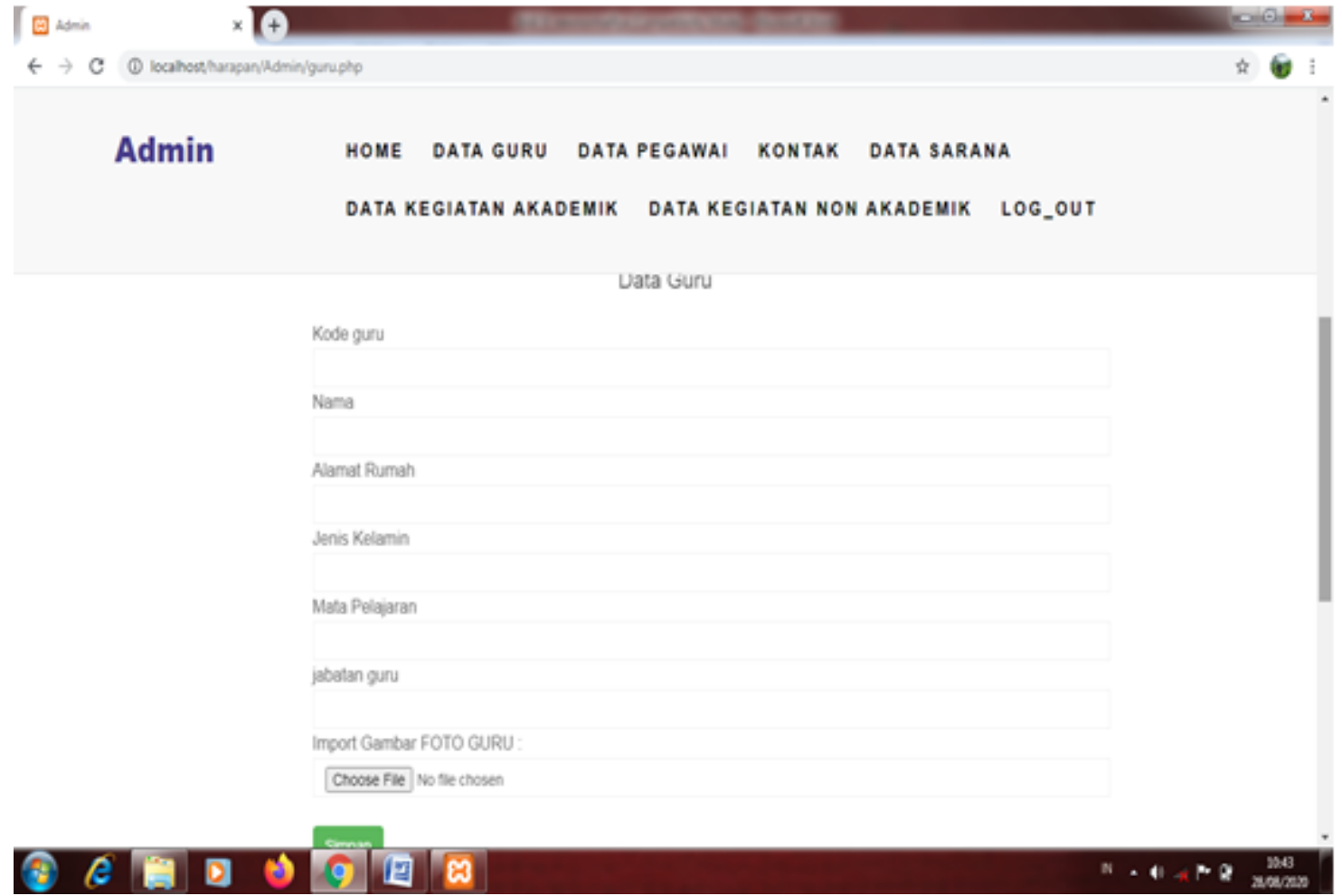

Keterangan :

- Admin terlebih dahulu harus mengisi kode guru dimana Id harus sesuai dengan masing-masing guru.

- Setelah itu admin mengisi nama, alamat, jenis kelamin, mata pelajaran, jabatan dan masukkan foto kemudian pilih tombol simpan.

- Jika admin ingin melakukan perubahan admin harus menginput kembali data yang ingin dirubah, jika data sudah ditampilkan pilih tombol ubah.

- Jika admin ingin menghapus data maka pilih tombol hapus yang tersedia di dalam tabel. 


\section{PEMBAHASAN}

\section{Tujuan Implementasi Sistem}

Tujuan implementasi sistem adalah sebagai berikut:

1. Menyelesaikan desain sistem yang ada dalam dokumen desain sistem yang disetujui.

2. Menulis, menguji, dan mendokumentasikan program-program dan prosedur-prosedur yang dilakukan oleh dokumen desain sistem yang disetujui.

3. Memastikan bahwa konversi ke sistem baru berjalan secara benar yaitu dengan merencanakan, mengontrol dan melakukan instansi sistem baru secara benar.

\section{Pembahasan Sistem}

Pendidikan merupakan sarana penting untuk menciptakan sumber daya manusia yang mampu berkompetitif dalam kemajuan bangsa. Informasi sekolah yang hanya dapat masyarakat peroleh melalui media cetak masih kurang cukup menjangkaunya secara luas. Seiring berjalan nya perkembangan teknologi teknologi dan komunikasi penyampaian informasi sekolah dapat disajikan dengan menggunakan website. Mengingat pentingnya penyampaian informasi profil sekolah bagi masyarakat maka dibutuhkan sistem yang dapat menyajikan informasi sekolah secara akurat dan mudah dipahami masyarakat. Perancangan website profil sekolah Mtsn 2 Medan menggunakan PHP dan MySQL serta Dreamweaver sebagai media untuk penulisan koding. Website ini berisi informasi tentang profil sekolah seperti visi dan misi, kemudian informasi fasilitas sekolah, prestasi sekolah yang dapat memberikan gambaran tentang sekolah tersebut. Sehingga orang tua dapat memilih sekolah untuk putraputrinya sesuai bakat dan minat sang anak.

Dengan adanya website ini dapat memberikan informasi yang dibutuhkan oleh masyarakat mengenai Sekolah Mtsn 2 Medan. Dalam suatu sistem yang dirancang memliki kendala yang di hadapi oleh pengguna sistem. Untuk itu dilakukan evaluasi sistem yang bisa menjadi acuan dalam perombakan sistem dan update sistem yang dibangun agar mempermudah pengguna. Adapun kelemahan dan kelebihan sistem sebagai berikut:

\section{Kelebihan Sistem}

1. Sistem yang dibangun berupa website sistem informasi menampilkan informasi tentang sekolah.

2. Sistem ini menggunakan design template boostrap dan tampilan css lebih dinamis tampilan mobile. 
Cybernetics: Journal of Research and Educational Studies

Volume 2 Nomor 4, Oktober 2021

Halaman 81-95

3. Sistem dibuat dengan tampilan sederhana dan mudah digunakan oleh user ataupun admin.

\section{Kelemahan Sistem}

1. Sistem yang menampilkan outpu berupa informasi dan sistemy tidak ada dalam penginputan data.

2. Sistem tidak menggunakan framework dalam tampilan template php.

\section{KESIMPULAN}

Setelah proses perancangan website Profil Sekolah Madrasah Tsanawiyah Negeri 2 medan Adapun beberapa kesimpulan yang dapat disampaikan sebagai hasil evaluasi dalam laporan tugas akhir ini adalah sebagai berikut:

1. Mengetahui profil sekolah Madrasah Tsanawiyah Negeri 2 Medan dilakukan dengan menggunakan brosur, pamplet dan informasi melalu siswa itu sendiri.

2. Merancang aplikasi profil sekolah Madrasah Tsanawiyah Negeri 2 Medan dilakukan dengan menggunakan DFD (data Flow Diagram), peracangan use case digram, diagram konteks program PHP dan MySQL.

3. Mengimplentasikan dengan menjalankan aplikasi tersebut dan memperaktekkan langsung di sekolah apakah sistem tersebut berjalan atau tidak. Kalau sukses berarti sistem siap dioperasikan sesuai dengan pengembangan yang akan terus dilakukan user.

\section{REFERENCE}

Amrullah, Afif. 2009. Unified Modeling Language (UML). Pustaka. Bandung.

B. Indra Yatini, 2010. Flowchart, Algoritma dan Pemrograman Menggunakan Bahasa C++. Penerbit Graha Ilmu. Yogyakarta.

Edy Winarno ST, M.Eng. 2002. Panduan Lengkap Berinternet. PT Elex Media Komputindo. Jakarta.

Harminingtyas, Rudika. 2014. Analisis Layanan Website Sebagai Media Promosi, Media Transaksi dan Media Informasi dan Pengaruhnya Terhadap Brand Image Perusahaan pada Hotel Ciputra di Kota Semarang. Jurnal STIE Semarang, Vol 6, No. 3.

Hasugian, Penda Sudarto. 2018. Perancangan Website Sebagai Media Promosi dan Informasi. Journal Of Informatic Pelita Nusantara, Volume 3.

Heriyanto, Yunahar. 2018. Perancangan Sistem Informasi Rental Mobil Berbasis Web pada PT. APM Rent Car. Jurnal Intra-Tech, Vol 2, No. 2.

Lavarino, Dio dan Wiyli Yustanti. 2016. Rancang Bangun E-Voting Berbasis Website di Universitas Negeri Surabaya. Jurnal Manajemen Informatika, Volume 6 Nomor 1. 
Cybernetics: Journal of Research and Educational Studies

Volume 2 Nomor 4, Oktober 2021

Halaman 81-95

Mauko, Imanuel Christian, dkk. 2017. Pengembangan Website Unit Penelitian dan Pengabdian Kepada Masyarakat dan Penerapan Jurnal Elektronik Berbasis Open Source di Politeknik Negeri Kupang. Jurnal Ilmiah Flash, Volume 3, No. 2.

Narbuko, Drs. Cholid dan Drs. H. Abu Achmadi,.2012. Metodologi Penelitian. Bumi Aksara. Jakarta.

Prajoso, Lantip Diat. 2014. Perancangan Database Sistem Informasi Manajemen Pendidikan Dengan DBMS Microsoft Acces dan SQL Server. Uny Prees. Kampus Uny Karangmalang. Yogyakarta.

Prastowo, Andi. 2012. Metode Penelitian Penelitian Kualitatif Dalam Persektif Rancangan Penelitian. Ar-ruzzmedia. Yogyakarta.

Rosa A. S dan M. Shalahuddin. 2018. Rekayasa Perangkat Lunak. Penerbit Informatika Bandung. Bandung.

Susanto, Bob. 2015. 12 Tipe dan Pengertian Database Menurut Para Ahli. http://www.seputarpengetahuan.com/2015/02/12-tipe-dan-pengertiandatabase-menurut-para-ahli.html.

Tim EMS. 2014. Teori dan Praktik PHP-MySQL untuk Pemula. PT Elex Media Komputindo. Jakarta.

Yakub. 2012. Pengantar Sistem Informasi. Penerbit Graha Ilmu. Yogyakarta. 